\author{
Л. В. Рацибурская \\ Нижегородский государственный университет им. Н. И. Лобачевского \\ (Россия, Нижний Новгород) \\ racib@yandex.ru
}

\title{
ПОЛИКОДОВОСТЬ В МЕДИЙНОМ СЛОВОТВОРЧЕСТВЕ КАК СРЕДСТВО РЕЧЕВОГО ВОЗДЕЙСТВИЯ*
}

На рубеже веков медийная коммуникация стала важнейшим общественным институтом, оказывающим влияние на упорядочивание социально значимой информации, качество публичного дискурса, создание альтернативной реальности, формирование моральных норм, эстетических вкусов, выстраивание иерархии ценностей. Характерной чертой современного медиатекста является его поликодовость как взаимодействие средств разных кодовых систем (буквенных и небуквенных средств воздействия: шрифтов, цифр, идеографических знаков, символов, колористики, рисунков, фото). В статье рассматриваются новые аспекты медийного словотворчества, связанные с поликодовым характером современного медиатекста: использование в новообразованиях — графических гибридах — разнофункциональных элементов одного языка (дефисация, парантезис, квотация, синграфемия), а также элементов разных кодовых систем (элементов алфавитов разных языков, разных шрифтов, цифр, идеограмм, рисунков, цвета). Поликодовость медийного словотворчества является эффективным средством речевого воздействия. В статье характеризуется функциональная специфика гибридных новообразований как экспрессивно-оценочного средства, средства суггестии и манипуляции в современных медиатекстах. Coвременное медийное словотворчество свидетельствует о том, что автор медиатекста выступает выразителем чьих-либо интересов, представляет то или иное сообщество, группу, партию и в соответствии с целями этого сообщества моделирует при помощи объективированных в текстовом формате стереотипных представлений реальность.

Ключевые слова: медиатекст, поликодовость, новообразования, графические гибриды, речевое воздействие.

На рубеже XX-XXI вв. динамическое развитие СМИ привело к созданию глобального информационного пространства. Медийная коммуникация стала

* Работа выполнена при финансовой поддержке РФФИ, проект 18-012-00195. 
важнейшим общественным институтом, оказывающим влияние на упорядочивание социально значимой информации, качество публичного дискурса, создание альтернативной реальности, формирование моральных норм, эстетических вкусов, выстраивание иерархии ценностей. По словам М. Н. Володиной, «адресату передается не только некое сообщение о событии, но и (эксплицитно и имплицитно) позиция автора / инициатора текста, представляющая интерпретацию данного события. Именно массмедиа «призваны» способствовать оценке окружающей действительности, воздействуя на общественное сознание и моделируя соответствующую картину мира» [Володина 2015: 21]. Как отмечают ученые, «современные СМИ все жестче манипулируют сознанием масс с помощью растиражированных стандартов поведения. Стараясь донести до потребителя информацию, СМИ выполняют свою важнейшую задачу - сделать так, чтобы в массовом сознании эта информация вызвала реакции, соответствующие требованиям заказчика, в лице которого могут выступать как частные лица, так и государство» [Конюхова 2005: 71].

Проблема речевого воздействия приобрела в российском обществе на рубеже XX-XXI вв. особую актуальность. Либерализация социально-экономических отношений, развитие вместе с рынком рекламы как стратегии навязывания товара, плюрализм в политике, изменения в системе управления, возрастание роли отдельной личности - все эти факторы обусловили актуализацию средств и форм речевого воздействия.

Журналистский текст представляет собой сложное целое. По мнению ученых, он отличается одноразовостью и невоспроизводимостью, коллективным характером производства, открытостью для многочисленных интерпретаций, диалогичностью, оценочностью, эмоциональностью, суггестивным характером, поликодовостью. Поликодовость как взаимодействие разных кодовых систем является в настоящее время эффективным средством воздействия.

Восприятие сообщения происходит на разных уровнях: зрительном (печатные СМИ), слуховом (радио), зрительно-слуховом (телевидение, интернет). По словам Т. Г. Добросклонской [2016: 14], «в массмедиа вербальный текст все более замещается мультимедийным, его словесная составляющая иллюстрируется, дополняется, многократно усиливается медийным компонентом - рисунком, фотографией, видеорядом, особым шрифтом и т.д., создавая визуальные образы, оказывающие мощное воздействие на сознание человека». Таким образом, вербальное существует «в поликодовом пространстве, наряду с аудиальным, визуальным, кинетическим компонентами» [Чернявская 2013: 10].

Поликодовость характеризует и современное медийное словотворчество, в котором представлены прежде всего такие формы речевого воздействия, как суггестивность и манипулирование. Суггестивность как внушение, исключающее рациональное начало, опирается прежде всего на чувственно-ассоциативные стороны сознания. Отсюда особая воздействующая функция невербальной составляющей новообразований. Визуализация коммуникации заставила ученых обратить особое внимание на «визуальные неологизмы» (Е. В. Маринова) - графические гибриды, образования вербально-иконической природы. 
Представленная в науке классификация графических гибридов учитывает различные средства их создания, сочетающиеся в рамках слова [Попова 2013: 149]. Проявлением поликодовости в медийных новообразованиях считается использование разнофункциональных элементов одного языка (кодографиксация, по Т.В. Поповой):

- дефисация: Ре-анимация - повторное оживление, восстановление (Комсомольская правда, 16.06.2001); Непростое оно, ино-странное счастье (Комсомольская правда, 27.02.2003) - о невестах, которые ищут счастье за границей; Не-опера-тивное строительство. Ещё в 2008 году началась разработка проекта, а в 2011-м губернатор Валерий Шаниев объявил, что в ближайшие три года новое здание театра оперы и балета будет построено (Патриоты Нижнего, 25.11.2015); Пент-агония (Завтра, 2015, №45); Веаиtу Гала-ктика. В город пришло солнще, а вместе с ним и бьюти новинки, которые выдержат строгую проверку Гала Мари@gala.mari (Собака.pу, 07.08.2017);

- квотация: «ЛЮБЭ»вный треугольник. Расторгуев сыграет в пьесе Максимова «Любовь в двух действиях» (Новая газета, 10.06.2002, №4); Брызги «Фонтан»ского (Литературная газета, 30.04-06.05.2003) — о новом ресторане «Фонтан» в Одессе; «Нано»подкоп под Чубайса (Московский комсомолец, 04.07.2015); Савченко по-«евро»пейски. На этот раз в суде выступили хозяева воронежской гостиницы «Евро», которые не смогли представить ни одного доказательства проживания у себя подозреваемой (Московский комсомолец, 29.10.2015); «МиГ»нуть не успеете. Новые МиГи-35 будут собирать на заводе «Сокол» в Нижнем Новгороде (Патриоты Нижнего, 26.07.2017);

- парентезис: Про(и)зрачная комиссия (Аргументы и факты - Черноземье, 2002, № 8); Унифик(а)ция (Известия, 29.10.2003); (Не)новые медиа (Журналист, 2016, № 11); Это (не)экстремистский текст! (Русский репортер, 2017, №8) о запрещенной и экстремистской секте «Свидетели Иеговы»; 5 причин (не)любить молодых (Psyhologies, 07.2017); Лекарство от с(к)уки (Cosmo, 09.2017); В этом году ЭПИДЕМИИ (не) БУДЕТ? (Женские советы, 01.2018);

— пунктуационное варьирование (синграфемия): Пост,модерн (Elle, 12.2017)— о моде поститься.

Ярким средством визуального воздействия является использование прописных и строчных букв а рамках одного слова, так называемый прием капитализации, при котором в одном узуальном слове выделяется часть, соответствующая другому узуальному слову, нередко с формальными видоизменениями: Жировки всПЕНИлись. В октябрьских платежках будут начислены долги за неуплату по статье «капремонт» (Нижегородский рабочий, 28.09.2016); ФОКус не удался. Область завернула спортпроект на миллиард (Саров.Net, 18.03.2016); В. Tретьяк: эВРИстика тренера. (Наша психология, 06-07.2017); Кончилось терПЕНие. Писательская среда давно не знала таких волнений. За несколько дней из русского ПЕН-иентра вышел ряд людей с национальной и мировой известностью (Газета. ru, 14.01.2017); Пермяк поРОБОТил мир (Комсомольская правда, 02-09.03.2016).

Как проявление креолизованности можно рассматривать элементы алфавитов разных естественных языков в рамках одного новообразования: Около плинmUSA. 
Америка сегодня «около плинтуса». Или даже так - «около плинтUSA» (Завтра, 2015, №34); SOSEДИ (название рубрики, Московский комсомолец, 28.06.2017); NEГОЛОДНЫЙ Пиарщик (Собака.ру, 07-08.2017); Идентификаџия ВJORNa (Русский репортер, 11-12.2017) - прецедентное обыгрывание названия фильма «Идентификация Борна»; Tinder-cюрприз. Как сервис знакомств используют для найма сотрудников (Новостной портал RBK, 14.09.2016); ARD-обстрел, пятая серия. В фильме журналиста Зеппельта на канале ARD российский легкоатлет стал главным информатором (Московский комсомолец, 24.01.2017). В последних двух случаях совмещение разных алфавитов сопровождается контаминацией: киндерсюрприз + Tinder, арт-обстрел + ARD.

По словам Е.А. Земской, «манипулирование двумя алфавитами, кириллическим и латинским, используется как средство привлечения внимания, создания особой выразительности» [Земская 2001: 192]. Проявлением поликодовости является также использование элементов разных кодовых систем:

- элементов алфавита естественного языка и цифр: ПРО100 ссорит банкиров. Для банковского приложения УЭК используется система ПРО100 (Нижегородская правда, 08.04.2014); Про100 концерт (Горбатка.ру, 27.11.2017). Составители рекламных текстов в основном играют с числом 100, которое может использоваться не только для обозначения количества, но и как показатель высокого качества: Ha100\%ящие джинсbl. По словам Земской, «этот прием действует не только в русском языке. Он широко распространен в США в рекламе, в вывесках и других видах письменности» [Земская 2007: 192].

- элементов алфавита естественного языка и идеограмм: И denymambl y нас ... ненастоящие. И\$ку\$твєнныЄ (Московский комсомолец, 17-24.07.2013); Сделайте нам пол $\boldsymbol{t}^{\circ}$ еплым;

Использование цветовых элементов - еще одно поликодовое средство в рамках графогибридизации: Вот такая олипивада; Кому поДАРочек? (Наша психология, июнь-июль 2017); ПОLOVEИНКИ (Cosmo, 09.2017). Игра с цветом рассматривается как мощный прием воздействия, поскольку отражает высокую биологическую зависимость человека от цветоощущения в социальной сфере: люди, подчиняясь тем или иным психологическим реакциям на свет, склонны наделять цвета определенным смыслом, выстраивать сложные ассоциации между палитрой того или иного образа и явлением, этим образом обозначенным [Бердышев 2008]. Так, красный цвет лидерства и энергии удачно сочетается с императивным характером провокационной эвокативности, побуждающей к действию, что наблюдается в заголовке Красныц триумф статьи о тренде красного цвета (Women's Health, 12.2017).

Использование рисунка, фотоэлементов также является выразительным и действенным средством поликодовости. Так, в заголовке Делай, как Kayla. Экспресс тренировка от Кайль Итсинес (Women's Health, 12.2017) девушка на фотографии, вмонтированной в имя собственное, одним ударом руки разбивает букву $l$.

Акцент на визуализации рассматривается учеными как коммуникативный вызов новейшего времени [Чернявская, Молодыченко 2017: 15]. По мнению 
исследователей, «настало время мультимедиальной стилистики, занимающейся стилевыми, экспрессивно-эмоциональными и выразительными приемами, средствами, формами и результатами интеграции языкового и неязыкового кодов» [Тошович 2018: 131].

Современное медийное словотворчество свидетельствует о том, что автор медиатекста выступает выразителем чьих-либо интересов, представляет то или иное сообщество, группу, партию и т.п. и в соответствии с целями этого сообщества моделирует при помощи объективированных в текстовом формате стереотипных представлений реальность [Мардиева 2017: 45].

\section{Литература}

Бердышев С.Н. Рекламный текст: методика составления и оформления. М.: Дашков и Ко, 2008. 252 с.

Володина М.Н. Социальная и информационно-языковая роль текстов массовой коммуникации // Жанры и типы текста в научном и медийном дискурсе / под ред. А. Г. Пастухова. Орел: Орловский гос. ин-т культуры, 2015. С. 20-26.

Добросклонская Т.Г. Методы анализа видео-вербальных текстов // Медиалингвистика. 2016. №2(12). С. 13-25.

Земская Е. А. Язык как деятельность: морфема, слово, речь. М.: Языки славянской культуры, 2001. 367 с.

Земская Е.A. Игровое словообразование // Язык в движении: к 70-летию Л.П. Крысина / Отв. ред. Е.А. Земская, М.Л. Каленчук. М.: Языки славянских культур, 2007. С. 186-194.

Конюхова Т.В. Влияние СМИ на массовое сознание в информационном обществе // Фундаментальные исследования. 2005. № 3. С. 71-72.

Мардиева Л.А. Социокультурная реальность и ее интерпретации в медиатекстах. Опыт интегративного исследования. Казань: Изд-во Казанского ун-та, 2016. $358 \mathrm{c}$.

Попова Т. В. Креолизованные дериваты как элемент русской письменной коммуникации рубежа XX-XXI вв. // Лингвистика креатива - 1: коллективная монография. Екатеринбург : Уральский государственный педагогический университет, 2013. С. 147-176.

Тошович Б. Семантика, стилистика и поэтика графодеривации // Вторые Григорьевские чтения. Неология как проблема лингвистической поэтики: Тезисы докладов международной научной конференции (14-16 марта 2018) / под ред. В. А. Плунгяна, Н. А. Фатеевой, Л. Л. Шестаковой, А.С. Кулевой. М.: Издательский центр «Азбуковник», 2018. С. 129-132.

Чернявская B.E. Текст в медиальном пространстве: Учебное пособие. М.: Книжный дом «ЛИБРОКОМ», 2013. 210 с.

Чернявская B.E., Молодыченко E.A. Речевое воздействие в политическом, рекламном и интернет-дискурсе: Учебник для магистратуры. М.: ЛЕНАНД, 2017. $167 \mathrm{c}$. 


\section{V. Ratsiburskaya \\ Lobachevsky State University of Nizhny Novgorod \\ (Russia, Nizhny Novgorod) \\ racib@yandex.ru}

\section{POLYCODE CHARACTER IN THE MEDIA CREATION OF WORDS AS A MEANS OF SPEECH INFLUENCE}

At the turn of the century, media communication has become the most important public institution influencing the ordering of socially significant information, the quality of public discourse, the creation of alternative reality, the formation of moral norms, aesthetic tastes, building a hierarchy of values. A characteristic feature of the modern media text is its polycode character as an interaction of means of different code systems (alphabetic and non-alphabetic means of influence: fonts, numbers, ideographic signs, symbols, coloring, drawings, photos). The article deals with new aspects of media word creation associated with polycode nature of contemporary media texts: use of neologisms - the graphical hybrids - multifunctional elements of one language (hyphenation, parenthesis, quotation, singraphemy), as well as the elements of different code systems (elements of alphabets of different languages, different fonts, numbers, ideograms, drawings, colors). The polycode character of media word creation is an effective means of speech influence. The article describes the functional specificity of hybrid neologisms as an expressive and evaluative means, means of suggestion and manipulation in modern media texts. Modern media word creation shows that the author of the media text acts as an expresser of someone's interests, represents a particular community, group, party and in accordance with the goals of this community, models reality with the help of stereotypes objectified in the text format.

Key words: media text, polycode character, neologism, graphic hybrids, speech effects.

\section{References}

Berdyshev S. N. Reklamnyi tekst: metodika sostavleniya i oformleniya. [Advertising text: methodology of drawing up and processing]. Moscow, Dashkov i Ko Publ., 2008. $252 \mathrm{p}$.

Chernyavskaya V.E. Tekst v medial'nom prostranstve: Uchebnoe posobie [Text in the medial space]. Moscow, Knizhnyi Dom «LIBROKOM» Publ., 2013. 210 p.

Chernyavskaya V.E., Molodychenko E.A. Rechevoe vozdejstvie v politicheskom, reklamnom i internet-diskurse: Uchebnik dlya magistratury. [Speech influence in political, advertising and Internet discourse]. Moscow, LENAND Publ., 2017. 167 p.

Dobrosklonskaya T.G. [Methods for analyzing video verbal texts]. Medialingvistika, 2016, no. 2 (12), pp. 13-25. (In Russ.).

Konyukhova T.V. [The influence of mass media on the mass consciousness in the information society]. Fundamental'nye issledovaniya, 2005, no. 3, pp. 71-72. (In Russ.). 
Mardieva L. A. Sociokul'turnaya real'nost' i ee interpretacii v mediatekstah. Opyt integrativnogo issledovaniya [Sociocultural reality and its interpretation in media texts. An experience of integrative research]. Kazan', Kazan’ Univ. Publ., 2016. 358 p.

Popova T.V. [Creolized derivatives as an element of Russian written communication at the turn of the $20^{\text {th }}$ century.]. Lingvistika kreativa - 1: kollektivnaya monografiya [Linguistics of the creative approach - 1: Collective monograph]. Ekaterinburg, Ural State Pedagogical Univ., 2013, pp. 147-176. (In Russ.).

Toshovich B. [Semantics, stylistics and poetics of graphoderivation]. Vtorye Grigor'evskie chteniya. Neologiya kak problema lingvisticheskoi poehtiki: Tezisy dokladov mezhdunarodnoi nauchnoi konferentsii (14-16 marta 2018). [Second Grigor'ev's readings. Neology as a problem of linguistic poetics: Proceedings of the international conference (March 14-16, 2018)]. Moscow, 2018, pp. 129-132. (In Russ.).

Volodina M. N. [Social and information-linguistic role of mass communication texts]. Zhanry i tipy teksta v nauchnom i mediinom diskurse [Genres and types of text in scientific and media discourse]. Orel, Orlovsky State Institute of Culture Publ.. 2015, pp. 20 26. (In Russ.)

Zemskaya E. A. Yazyk kak deyatel'nost': morfema, slovo, rech' [Language as an activity: morpheme, word, speech]. Moscow, Yazyki Slavyanskoi Kul'tury Publ., 2001. $367 \mathrm{p}$.

Zemskaya E. A. [Derivational game]. Yazyk $v$ dvizhenii: $k$ 70-letiyu L.P. Krysina. [Language in motion: to the $70^{\text {th }}$ anniversary of L.P. Krysin]. Moscow, Yazyki Slavyanskikh Kul'tur, 2007, pp. 186-194. (In Russ.) 